\title{
MERUMUSKAN ELEMEN “TAWURAN VIRTUAL” ANTAR FANS SEPAKBOLA DI INDONESIA
}

\author{
Faridhian Anshari
}

\author{
Fakultas Ilmu Komunikasi Universitas Pancasila Jakarta \\ faridhian@univpancasila.ac.id
}

Diajukan: 13-04-2018; Direview: 26-05-2018; Diterima: 27-06-2018;

\begin{abstract}
Currently, created a shift in the trend of a supporter war that normally occur in the real world to become football fans war in the virtual world. According to the observations of the researcher, this trend of virtual fans war it always happens in any postings containing information of two big European clubs, namely Barcelona and Real Madrid. The seeds of the dispute may also be spurred by favoring that impressed Instagram caption nor the shape of satire. Through the review of the methods of Conversation Analysis of the comments of the two most popular and activefootball themed Instagramaccount(@bola_gila) and (@berita_sepakbola),then this research managed to formulate elements of a war that consisted of five (5) types the football fans of the characters often appear in process virtual fans war. In addition, the study also yielded findings in the form of eight (8) different types of indicators trigger the creation of a virtual fans war, as well as three (3) forms of violence that often occurs during a fans war.
\end{abstract}

Keywords: Fans War, Virtual, Football, and Instagram.

\begin{abstract}
Abstrak
Saat ini, tercipta pergeseran tren tawuran supporter yang biasanya terjadi dalam dunia nyata menjadi tawuran fans sepakbola dalam dunia maya. Menurut observasi peneliti, tren "tawuran virtual" fans ini selalu terjadi dalam setiap postingan yang mengandung informasi dua klub besar Eropa, yaitu Barcelona dan Real Madrid. Bibit perselisihan juga dapat dipacu oleh caption Instagram yang terkesan memihak maupun berbentuk sindiran. Melalui tinjauan metode Conversation Analysis dari kolom komentar dua akun Instagram terpopuler (@bola_gila) dan teraktif (@) berita_sepakbola) yang bertemakan sepakbola, maka penelitian ini berhasil merumuskan elemen tawuran yang terdiri dari lima (5) tipe karakter fans sepakbola yang kerap muncul dalam proses tawuran virtual. Selain itu, penelitian ini juga menghasilkan temuan berupa delapan (8) jenis indikator pemicu terciptanya tawuran virtual, serta tiga (3) bentuk kekerasan yang sering terjadi selama tawuran.
\end{abstract}

Kata kunci: Tawuran, Virtual, Fans, Sepakbola, dan Instagram.

\section{PENDAHULUAN}

S osial media sudah menjadi kebutuhan seharihari sebagian orang di dunia, tidak terkecuali di Indonesia. Banyak pihak yang berpendapat bahwa, tanpa sosial media seperti facebook hingga Instagram, koneksi sosial dengan manusia lain jadi terbatas dan susah terjangkau. Pendapat yang tidak salah namun dapat juga dibantahkan. Seperti yang sering dikemukakan dalam berbagai kajain mengenai dampak new media, terutama sosial media, bahwa setiap penggunaan media baru dipastikan mempunyai dua sisi mata pisau yang sama-sama tajam. Selalu ada keuntungan maupun kerugian dari penggunaannya. Dennis McQuaill (2010) kerap mengucapkan bahwa kritik dalam penggunaan new media akan timbul, seiring menipisnya penggunaan dan eksistensi media tradisional yang berimbas kepada manajemen dan ekonomi media itu sendiri.

Penyebaran akan penggunaan sosial media juga merambah dalam dunia olahraga. Sisi utama yang paling menonjol dari dampak media baru ini adalah dari aspek meningkatnya loyalitas fans atau supporter (Boyle dan Haynes, 2009). Dalam 
konteks ini fans yang didefinisikan sebagai satu orang sekumpulan orang yang mencintai sebuah klub olahraga atau salah satu cabang olahraga, menjadi semakin bebas dalam mengekspresikan apa yang ada dibenaknya terkait kecintaanya yang sangat mendalam. Berdasarkan data yang dikeluarkan oleh kementerian Pemuda dan Olahraga (2015), maka akan mengerucut dalam tiga cabang olahraga yang digemari oleh penduduk Indonesia (baik sebagai penikmat permainannya maupun sebagai spectators: pengamat atau penontonnya saja). Sepakbola, kemudian disusul bulutangkis, dan tinju sebagai peringkat ketiga menjadi tiga cabang olahraga yang paling digemari di Indonesia.

Sepakbola selalu menjadi cabang olahraga yang paling diminati oleh berbagai negara dibelahan dunia, sebagai permainan maupun sebagai olahraga yang cukup diamati atau ditonton. Berdasarkan riset yang diungkapkan oleh Iswandi Syahputra dalam karyanya "Pemuja Sepakbola: Kuasa Media Atas Budaya" (2016), bahwa khalayak penikmat sepakbola di Indonesia terbagi dalam dua tipe besar, yakni sebagai supporter yang mendukung dan menonton sepakbola secara langsung dilapangan dan fans yang bertindak sebagai pengamat saja, tanpa harus ikut berpeluh keringat bermain sepakbola dilapangan, tetapi sangat mencintai klub yang dibelanya. Sehingga terlihat perbedaan yang signifikan dalam membedah penelitian mengenai supporter dalam media.

Fans, khususnya Supporter sepakbola di Indonesia sering diidentifikasian dengan istilah tawuran. Kata tawuran sendiri dalam Kamus Besar Bahasa Indonesia (2008) mempunyai arti sebagai perkelahian massal, yang melibatkan minimal dua pihak tertentu. Dalam konteks sepakbola, tawuran supporter sendiri sering acapkali terjadi karena perselisihan antara supporter sebuah klub dengan supporter klub lainnya dikarenakan rasa fanatisme yang berlebihan. Salah satunya dapat timbul dari perasaan marah atau tidak puas hingga tidak dapat menerima hasil akhir pertandingan yang didapatkan oleh klub kecintaanya. Perselisihan supporter terjadi hampir diberbagai negara dibelahan bumi, tidak hanya di Indonesia saja. Sejarah perselisihan antar supporter paling awal diketahui terjadi di negara Inggris, yang kemudian para supporter fanatiknya dikenal dengan nama The Hooligans
(Carnibella, 1996). Dalam bukunya "Tamasya Bola" (2016), Darmanto Simaepa menjelaskan bahwa perselisihan yang timbul antar supporter, sudah menjadi bagian hidup dari berbagai lapisan masyarakat di berbagai negara di dunia.

Franklin Foer dalam bukunya Memahami Dunia Lewat Sepakbola (2006) menjelaskan bahwa peperangan yang terjadi dalam sejarah peradaban dunia bahkan dapat timbul dari permasalahan sepakbola. Perang saudara di Serbia yang merupakan pecahan Uni Soviet adalah saksi hidup bagaimana sepakbola juga menjadi elemen yang melahirkan perdebatan antar pendukung yang bisa berakibat kepada perpecahan antar lapisan masyarakat. Namun disisi lain sepakbola yang mengedepankan reaksi antar supporter dan fans nya juga dapat meleburkan dinding-dinding perbedaan sosial antar lapisan masyarakat. Sudah menjadi hal lumrah, bahwa dalam sebuah pertandingan sepakbola kaum borjuis dapat bersanding dengan kaum buruh yang kastanya jauh berada dibawah (Beth, 2003).

Perkembangan zaman, yang turut menyertakan new media sebagai salah satu unsur besar didalamnya juga turut mewujudkan melebarnya tawuran supporter keranah baru. Berbagai perkelahaian supporter yang terjadi diberbagai belahan dunia, merupakan perkelahaian yang terjadi secara real didunia nyata. Perkelahian yang timbul, merupakan perselisihan yang lebih bersifat baku hantam secara nyata yang dilakuakn antar supporter kedua belah pihak. New media dengan dasar elemen internet serta bersifat tidak mengenal ruang dan waktu, turut melahirkan pertengkaran yang terjadi oleh supporter klub sepakbola yang berada dibelahan bumi bagian lain. Perkelahian antar supporter yang awalnya bersifat nyata, merambah ke perkelahian dalam dunia maya. Namun yang bukan supporter yang terlibat perang, namun jenis berbeda yakni fans.

Belum ada yang menemukan titik awal perkelahian antar fans dalam dunia maya, serta faktor-faktor utama yang mendorong lahirnya perselisihan lewat kata-kata yang tertuang secara virtual dan digital. Peneliti mencoba menemnukan berbagai faktor lahirnya perang kata-kata hingga gambar antar supporter dalam dunia maya, namun masih belum menemukan titik terang. Beberapa literatur merajuk kepada, pekelahian bisa timbul 
karena klub sepakbola yang dicintai oleh fans, turut hadir dalam dunia maya lewat akun resmi yang mengedepankan informasi cepat, benar, dan langsung dari "dapur" klub sepakbola tersebut. Hampir seluruh klub sepakbola besar didunia sudah mempunyai akun sosial media resmi (baik itu fan pages Facebook, akun Twitter, Google+, channel Youtube resmi, hingga akun Instagram). Di Indonesia sendiri, penggunaan sosial media oleh klub sepakbola sudah mulai berjalan semenjak tahun 2010, yang diawali oleh Persib dan Pesija. Hingga tahun 2014, hampir 80\% klub sepakbola peserta liga utama Indonesia telah menggunakan sosial media (terutama facebook) sebagai media interaksi, informasi, dan branding untuk supporter dan fans (Anshari \& Prastya, 2014).

Peneliti telah melakukan riset dengan melihat berapa banyak akun Instagram yang bertemakan berita sepakbola yang lahir di Indonesia. Per 1 Juli 2017, terdapat 45 akun Instagram berbahasa Indonesia yang membahas berita sepakbola sbeagai konten utamanya. Dari ke-45 akun tersebut, mempunyai jumlah followers yang beragam. Langkah berikutnya yang peneliti tempuh adalah menyaring ke 45 akun isntagram tersebut kedalam kategori akun Instagram dengan followers diatas 10.000 followers (biasanya dalam isntagram akan muncul huruf ' $\mathrm{K}$ ' disamping angka jumlah followers). Berdasarkan data yang ada, peneliti mendapatkan 21 akun Instagram yang mempunyai jumlah followers cukup banyak, diatas 10.000 followers. Langkah berikutnya adalah, peneliti mengerucutkan kembali 21 akun Instagram tersebut menjadi 5 akun Instagram yang paling banyak jumlah followersnya, maka akan dihasilkan data tabel 1.

Namun kategorisasi Instagram juga dapat dikur dari keaktifan tingkat pengunaan yang diwakilkan dari jumlah postingan yang tertera dalam beranda akun (lihat tabel 2). Dari data yang tertera, maka dapat dilihat bahwa kelima akun paling banyak jumlah followersnya, juga merupakan kelima akun yang paling aktif dari sisi postingannya. Untuk memepermudah ranah penelitian, peneliti memilih menggunakan dua akun Instagram yang merupakan akun terpopuler dan teraktif, yakni akun @bolagila dan@berita_sepakbola
Tabel 1. Akun IG terlaris per 1/7/2017

Sumber: Data observasi peneliti

\begin{tabular}{ccc}
\hline No & Nama Akun & $\begin{array}{c}\text { Jumlah } \\
\text { Followers }\end{array}$ \\
\hline $\mathbf{1}$ & Bolagila & $946 \mathrm{k}$ \\
\hline $\mathbf{2}$ & Berita_sepakbola & $593 \mathrm{k}$ \\
\hline $\mathbf{3}$ & Plesbol & $468 \mathrm{k}$ \\
\hline $\mathbf{4}$ & Seputar_bola & $395 \mathrm{k}$ \\
\hline $\mathbf{5}$ & Kepoball & $369 \mathrm{k}$ \\
\hline
\end{tabular}

Tabel 2. Akun Instagram teraktif per 1 Juli 2017 Sumber: Data observasi peneliti

\begin{tabular}{ccc}
\hline No & Nama Akun & $\begin{array}{c}\text { Jumlah } \\
\text { Postingan }\end{array}$ \\
\hline $\mathbf{1}$ & Berita_sepakbola & 18.662 post \\
\hline $\mathbf{2}$ & Kepoball & 12.551 post \\
\hline $\mathbf{3}$ & Bolagila & 10.162 post \\
\hline $\mathbf{4}$ & Plesbol & 8.963 post \\
\hline $\mathbf{5}$ & Seputar_bola & 8.753 post \\
\hline
\end{tabular}

Hal lain yang menjadi batasan dalam penelitian ini adalah penggunaan studi kasus dalam masingmasing postingan akun Instagram. Setiap akun mempunyai konten berita berbeda yang akan diposting walaupun masih dalam satu tema besar yaitu berita sepakbola. Agar penelitian ini menjadi spesifik dan tersudut pada satu berita yang sama, maka diperlukan penyeragaman berita yang akan dijadikan sebagai objek analisis, yang nantinya akan dilihat lebih jauh dalam postingan komentar fans dalam kolom komentar Instagram. Studi kasus yang peneliti angkat adalah final Liga Champions UEFA musim 2016/2017 yang dilangsungkan pada tanggal 3 Juni 2017.

Situs media olahraga cultureindo.com pada pertengahan tahun 2017 mencatat bahwa Barcelona menempati posisi tertinggi sebagai klub sepakbola yang mempunyai jumlah fans terbanyak di Indonesia (kurang lebih sebanyak 49 juta jiwa). Posisi kedua disusul oleh Real Madrid yang memiliki pengikut di Indonesia sebanyak kurang lebih 46 juta jiwa. Posisi berikutnya baru diikuti oleh beberapa klub asal Inggris, Manchaster United dan klub asal italia, Juventus (www. cultureindo.com). Dari data tersebut dapat ditarik bahwa sebenarnya persaingan Barcelona dan Real Madrid sebagai dua klub besar Eropa rasa Spanyol, 
juga telah melebar keluar arena lapangan hijau. Persaingan dalam jumlah fansbase dan supporter di seluruh penjuru dunia juga menjadi "indikator persaingan" lain oleh kedua klub besar ini.

Hal lain yang dapat dicermati adalah peranan caption yang dituliskan oleh akun Instagram bertemakan berita sepakbola di Indonesia. Berdasarkan pengamatan peneliti, tawuran fans dalam dunia maya terutama dalam kolom komentar Instagram dapat dipicu oleh tiga unsur utama, yakni: Caption yang ditulis oleh admin, gambar dari postingan admin, maupun kata-kata yang tertuang dalam kolom komentar. Peranan sang admin akun Instagram menjadi penting disini. Contoh utama dapat dilihat dari postingan akun Instagram @ bolagila sebagai pemilik akun terbanyak diikuti di Indonesia. Dalam postingannya pada tanggal 4 juni 2017, beberapa menit setelah Real Madrid memenangi final UEFA liga champions 2017, admin akun@bolagila menuliskan caption yang menyindir pihak supporter Barcelona (dapat dilihat dalam gambar 1).

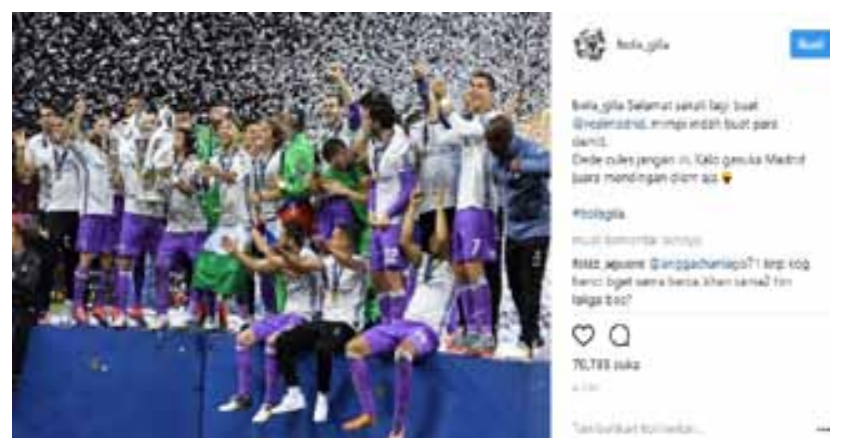

Gambar 1. Potingan akun Instagram @bolagila t erkait kemenangan Real Madrid dalam final UCL 2017.

Sepakbola diciptakan dan dikumandangakan oleh Jules Rimet untuk menciptakan perdamaian dan sebagai alat pemersatu, bukan sebagai alat pemecah hingga timbulnya perpecahan, tawuran, hingga perang yang saat ini mulai terlihat dalam dunia maya. Penelitian ini sendiri, mencoba mencari tahu secara rinci terkait elemen perselisishan dalam dunia olahraga yang meliputi pola, tipe perusuh, pemicu pertengkaran, hingga bentuk perselisihan (Cashmore \& Cleland, 2014) yang dapat diamati dalam kolom komentar kedua akun Instagram tersebut. Sehingga rumusan masalah dalam penelitian ini adalah elemen tawuran virtual yang meliputi bagaimana pola yang terjadi dalam tawuran virtual; bagaimana karakteristik fans yang terlibat sehingga menimbulkan pemicu dalam tawuran virtual dan apa saja bentuk kemarahan dalam tawuran virtual?

\section{LITERATUR DAN METODOLOGI Khalayak Sepakbola Dalam Wujud Supporter, Spectators, Followers, dan Fans.}

Orang awam, secara sederhana akan melihat keempat wujud supporter, Spektator, followers, dan fans sebagai bentuk yang sama. Munro dalam literaturnya: Sports Fan Culture and Brand Community (2006), mencoba menyempurnakan temuan yang sempat diangkat oleh Richard Giulianotti terkait definisi dan perbedaan jenis supporter sepakbola. Munro berhasil mendefinisikan tipe khalayak sepakbola menggunakan pisau sosialogi serta identitas budaya menjadi seorang pendukung sepakbola. Sehingga, khalayak sepakbola yang kemudian dikenal luas dengan berbagai nama, berhasil di bagi ke dalam empat jenis karakter dan tipe yang berbeda, yakni: spectators (penonton), supporters (pendukung), followers (pengikut), dan fans (penggemar).

Jika ditelusuri lebih dalam, maka Giulianotti (2006), menggambarkan kelima karakter tersebut secara sangat spesifik. Spektator lebih dilukiskan sebagai sekumpulan orang yang menonton suatu pertandingan baik itu langsung di stadion ataupun lewat media televisi, spektator sendiri lebih sering digambarkan sebagai orang netral yang menonton sepakbola sebagai hiburan, sehingga tidak mempunyai tedensius berlebih akan sebuah tim tertentu. Sementara itu, supporter digambarkan lebih spesifik dibandingkan spektator. Supporter didefinisikan sebagai penonton yang memberikan dukungan terhadap satu klub sepakbola yang sedang bertanding. Mereka bisa saja berasal dari fans klub sepakbola yang bertanding, atau bisa saja orang yang hanya ingin mendukung sebuah klub. Kata "support" sendiri digambarkan lebih tajam yang bersifat simpatik yang lebih menjurus kepada tertarik sesaat.

Jenis berikutnya, followers digambarkan mempunyai ikatan yang lebih dalam dari supporter. Followers didefinisikan sebagai orang yang menonton dan mendukung sebuah klub sepakbola karena mengikuti orang lain. Banyak faktor yang coba digali lebih dalam dari definisi ini. Faktor 
yang sering muncul karena mulai adanya rasa tertarik berlebih dari sekedar menonton menjadi mengikuti, namun menjurus kerasa yang lebih dalam untuk menjadi bagian dari fans sebuah klub sepakbola. Jenis berikutnya yang merupakan fans, digambarkan adalah tingkat tertinggi karena menggemari sebuah klub sepakbola. Mereka adalah sekumpulan orang yang memiliki ikatan emosional yang kuat dengan salah satu klub. Fans sendiri dapat terbentuk karena budaya turun temurun yang dibina dalam sebuah lingkaran inner seseorang, atau juga bisa lahir karena ikatan emosional yang berawal dari tingakatan seseorang masih menjadi spektator maupun supporter.

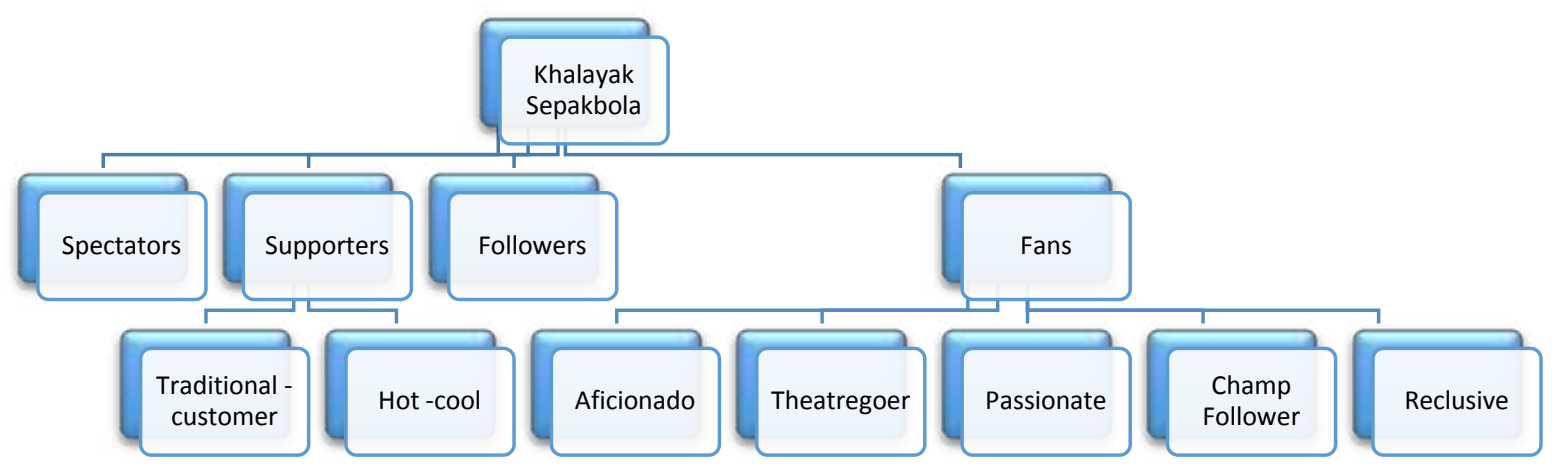

Bagan 1. Pemecahan jenis khalayak sepakbola, yang diungkapkan oleh Giulianotti (2006) dan Munro (2006).

Data: olahan peneliti.

\section{Karakter Fans Sepakbola Sebagai Pembeda dengan Karakter Supporter.}

Perasaan yang muncul dalam seorang fans adalah ikatan emosional karena sangat mencintai klub tersebut. Sedangkan fans yang berkembang dalam jumlah lebih besar dapat dikategorikan sebagai fanship, yang mempunyai definisi sebagai afiliasi dimana banyak makna emosional dan nilai yang beasal dari keanggotaan kelmpok. Fanship sendiri lebih berupa kumpulan kelompok orang yang menikmati sepakbola dan mencurahkan perhatiannya untuk berfikir, berbicara, dan berorientasi pada satu klub sepakbola yang digemarinya (Jacobson dalam Syahputra, 2016). Kata kunci yang coba diungkpakan oleh Jacobson adalah kegairahan dan keterikatan batin yang hanya dimiliki oleh sekumpulan fans klub sepakbola.

Di Indonesia sendiri, rasa keterikatan tersebut muncul, lebih karena keterikatan yang dipengaruhi oleh media massa. Followers sosial media Instagram klub sepakbola eropa yang berada di Indonesia lebih tepat dikategorikan sebagai karakter fans dibandingkan karakter sebagai seorang supporter. Berangkat dari definisi yang diutarakan oleh Munro (2006), bahwa supporter lebih bersifat sebagai pendukung langsung dilapangan selama pertandingan, sedangkan karakter follower Instagram lebih cocok dengan karakter fans yang mencintai klub tersebut tanpa harus menonton langsung dilapangan, namun selalu mengikuti perkembangan klub tersebut.

Dalam perkembangannya, karaktersitik fans sepakbola sendiri berhasil dikategorisasikan lebih rinci. Iswandi Syahputra (2016), mencoba mendefinisikan jenis fans sepakbola yang ada di Indonesia. Karaktersitik fans olahraga (khususnya sepakbola) ditinjau dari sisi motivasi dan perilaku fans. (Lihat Tabel 3)

Penelitian in menggunakan pendekatan kualitatif yang percaya bahwa fenomena yang dibentuk merupakan turunan dari masalah sosial yang ada dalam kehidupan sehari-hari. Sehingga proses pencariannya menggunakan ketepatan dan pemahaman yang tepat dalam melihat konstruksi sosial dan fenomena sosial yang ada (Wimmer \& Dominick, 2011). Penelitian ini menggunakan metode conversation analysis atau analisis percakapan yang masih terdapat kaitan dengan dicourse anaylsis atau analaisis wacana. Hal utama yang menjadikan conversation analysis berbeda dengan discourse analysis adalah pada letak penggunaan wacana sebagai unit analisisnya. Jika 
Tabel 3. Karakteristik Fans berdasarkan Perilaku dan Motivasi.

Diambil dari buku Pemuja Sepakbola karya Iswandi Syahputra, 2016.

\begin{tabular}{|c|c|c|c|}
\hline No & Jenis Fans & Motivasi & Perilaku \\
\hline 1 & Aficionado & $\begin{array}{l}\text { Mendukung klub karena } \\
\text { kualitas dan performa } \\
\text { klub }\end{array}$ & $\begin{array}{l}\text {-Mengikuti pertandingan klub. } \\
\text {-Memiliki klub lain, tapi tetap } \\
\text { setia pada klub asli. } \\
\text {-Tergabung dalam fansclub resmi }\end{array}$ \\
\hline 2 & Theatregoer & $\begin{array}{l}\text { Mendukung klub karena } \\
\text { mencari hiburan semata }\end{array}$ & $\begin{array}{l}\text {-Loyal kepada satu tim } \\
\text {-Loyalitas berubah jika terpuruk } \\
\text {-Menonton pertandingan klub } \\
\text { lain juga }\end{array}$ \\
\hline 3 & Passionate & $\begin{array}{l}\text { Mendukung klub karena } \\
\text { berharap timnya menang }\end{array}$ & $\begin{array}{l}\text {-Loyalitas jangka pendek } \\
\text {-Responsif terhadap klub saat } \\
\text { jaya atau terpuruk }\end{array}$ \\
\hline 4 & $\begin{array}{l}\text { Champ } \\
\text { Follower }\end{array}$ & $\begin{array}{l}\text { Mendukung klub ketika } \\
\text { klub pada masa kejayaan }\end{array}$ & $\begin{array}{l}\text {-Loyalitas jangka pendek } \\
\text {-Loyal kepada tim yang berjaya }\end{array}$ \\
\hline 5 & Reclusive & $\begin{array}{l}\text { Mendukung klub karena } \\
\text { partisan }\end{array}$ & $\begin{array}{l}\text {-Loyal kepada klub tetapi jarang } \\
\text { menonton pertandingan } \\
\text {-Memiliki identifikasi yang kuat }\end{array}$ \\
\hline
\end{tabular}

dalam analisis wacana menitikberatkan pada teks yang tersembunyi dan terlihat dalam media, maka dalam conversation analysis, unit analisis yang digunakan langsung tertuju pada percakapan atau dialog yang terjalin didalamnya.

Analisis percakapan dipilih serta dirasa tepat dalam penelitian ini karena dada dasarnya percakapan adalah manifestasi penggunaan bahasa untuk berinteraksi. Mey (2001:137) berpendapat bahwa wujud penggunaan bahasa tersebut dapat dilihatdariduaaspek.Aspekpertamaadalahisi,yaitu aspek yang memperhatikan hal-hal seperti topik atau konten yang didiskusikan dalam percakapan, bagaimana topik disampaikan dalam percakapan: apakah secara eksplisit, melalui presuposisi, atau diimplisitkan dengan berbagai macam langkah. Selain itu jenis topik yang dikemukakan apakah mengarah pada topik lain dan ada tidaknya alasan yang melatarbelakangi hal tersebut terjadi. Selain itu, fokus lain dari aspek ini adalah pola topik dalam percakapan dan bagaimana topik dikelola, baik disampaikan dengan cara terbuka maupun dengan manipulasi secara tertutup, yang biasanya dalam bentuk pembicaraan tidak langsung. Kedua adalah aspek formal percakapan. Fokus utama dalam aspek ini adalah hal-hal seperti bagaimana percakapan bekerja; aturan yang dipatuhi; dan bagaimana sequencing 'keberurutan' dapat dicapai dengan memberikan dan memperoleh giliran atau menggunakan mekanisme turn-taking, jeda, interupsi, maupun overlap.

Penelitian inimenitikberatkan kepada penemuan berbagai macam elemen fans sepakbola online yang tertuang dalam tawuran virtual di media sosial Instagram. Penggunaan analisis percakapan dirasa cukup tepat untuk menemukan rangkaian elemen yang saling berkaitan dalam tawuran fans sepakbola dalam dunia maya. Peneliti berharap, pembaca tidak mencari tahu mengenai jenis tawuran maupun proses dari terciptanya tawuran virtual ini. Sekali lagi, penelitian ini mempunyai fokus penelitian untuk melihat karakter, pola, pemicu, dan bentuk kemarahan yang timbul dari fans sepakbola ketika terjadi tawuran virtual di media sosial Instagram, bukan mengenai bagaiamana tahapan, langkah, proses hingga strategi tawuran virtual itu sendiri yang menjadi batasan penelitian.

\section{DISKUSI \\ Pola Tawuran Sepakbola Dalam Dunia Maya.}

Beberapa temuan dan observasi yang terangkum dalam Republik Gila Bola (Ubaidillah, 2008), menceritakan bahwa dapat terjadi dalam fase sebelum pertandingan sepakbola berlangsung, ketika pertandingan dilangsungkan dalam stadion, dan sesudah pertandingan selesai yang menentukan 
siapa tim yang dapat meraih kemenangan dan yang harus tertunduk lesu meratapi nasib kekalahan.

Fase tawuran supporter sesudah pertandingan, adalah tawuran yang sangat sering terjadi hampir disetiap pertandingan sepakbola dalam dunia nyata karena melibatkan baku hantam dan kekerasan fisik yang dapat menyebabkan banyak pihak. Indikator hasil kemenangan dan kekalahan yang menjadi pemicu utama dari perkelahian massa antar supporter. Menariknya, hal yang sama juga terjadi dalam "tawuran virtual" di setiap pertandingan sepakbola yang melibatkan pertarungan fans nya dalam dunia maya. Tawuran antar fans juga sering terjadi sebelum pertandingan berlangsung. Dalam hal ini, sering terjadi peperangan antar kata dalam sosial media yang melibatkan "adu prestasi" antar masing-maisng klub yang didukung oleh fans. Selama pertandingan berlangsung, juga menjadi fase "tawuran virtual" yang cukup menarik untuk ditunggu. Berdasarkan observasi peneliti, fase tawuran virtual selama pertandingan berlangsung (yang biasanya ditayangakan live oleh sosial media, maupun dalam wujud update skor oleh masing-masing akun sosial media) belum akan memunculkan benih-benih kebencian dibandingkan fase selanjutnya. Fase yang paling berbahaya dan yang akan menimbulkan perang komentar, adlah fase sesudah pertandingan berlangsung. Skor akhir menjadi indikator paling wahid dalam memunculkan perang kata-kata antar fans.

Perbedaan yang cukup mendasar jika melihat pola yang terjadi dalam "tawuran virtual" adalah peperangan dapat melibatkan empat pihak yang berbeda, yakni sang pemilik atau admin akun, fans klub sepakbola yang menang, dan fans klub sepakbola yang kalah, serta fans klub lain yang ikut dalam percakapan. Bandingkan dengan tawuran dalam sepakbola dunia nyata, pola yang terjadi hanyalah antar supporter klub.

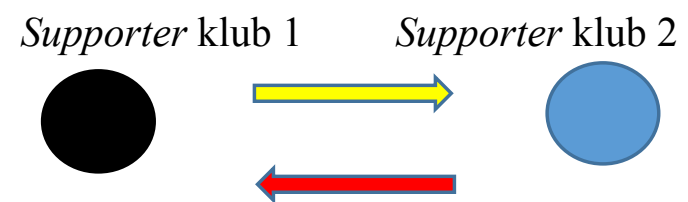

Gambar 2. Pola tawuran sepakbola dunia nyata. Pemilik/Admin Akun

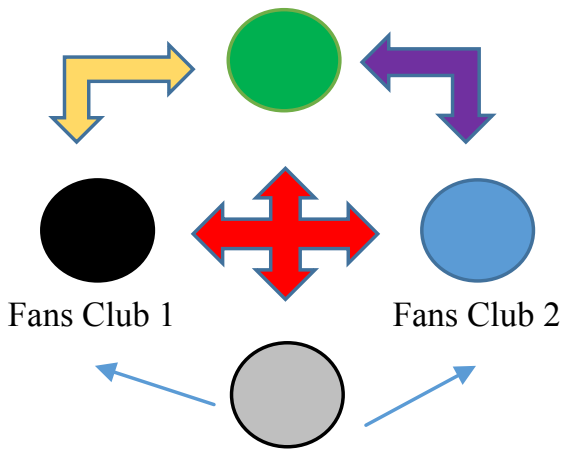

Fans Netral

Gambar 3. Pola tawuran sepakbola dunia maya.

Pola komunikasi yang biasa terjadi adalah, topdown, yang semua berawal dari postingan admin Instagram. Disini letak keunikan yang terjadi dalam tawuran virtual. Setiap posting yang dikeluarkan oleh pihak admin, tidak selalu menyindir atau menyudutkan salah satu pihak, namun tetap akan menghasilkan perselisishan dibagian followers atau fans. Faktor yang timbul bisa dari saling mengejek antar followers, hingga masalah skor akhir. Peran fans netral yang biasanya menjadi followers Instagram, tidak akan berpengaruh cukup banyak dalam menghentikan tawuran dalam kolom komentar.

Namun, tawuran virtual akan lebih berbahaya jika posisi admin sebagai komunikator pesan ikut memberikan kalimat ejekan atau sindiran melalui caption utama. Dampak yang dihasilkan akan sangat beragam. Chaos dapat terjadi dalam kolom komentar Instagram akun tersebut. Karena pola yang dihasilkan adalah caci maki antar kedua fans, ditambah masih adanya balas ejekan yang langsung ditujukan kepada admin sebagai pemicu, serta masih adanya peran fans netral yang mencoba menengahi yang kerapkali malah menambah keributan.

\section{Merangkai Hubungan Karakter Fans Sepakbola Sebagai Pemicu Tawuran.}

Perang kata-kata dalam tawuran virtual yang melibatkan fans sepakbola antar klub yang berbeda juga berhasil memunculkan karaktersitik yang beragam. Lewat metode conversation analysis, peneliti berhasil menghimpun lima karakteristik utama dari fans sepakbola Indonesia yang terlibat 
dalam tawuran virtual di kolom Instagram. Studi kasus yang digunakana adalah tawuran virtual ketika sebelum-sedang-sesudah pertandingan Final Liga champions 2017 berlangsung pada 4 Juni 2017. Final yang melibakan pertikaian fans dua klub Real Madrid dan Juventus, juga turut menyeret fans klub Barcelona dalam roda perselisihan. Sehingga, cukup dimengerti bahwa dalam konteks ini akan sering muncul perdebatan yang melibatkan decul (sebutan untuk fans Barcelona di Indonesia). Namun, karena dorongan dan pancingan dari postingan admin (liat gambar dibawah ini), maka mau tidak mau fans Barcelona akan ikut besuara dan menjalin perang kata-kata.

\section{0,706 likes demit. \\ \#bolagila \\ View all 1395 comments \\ 4 JUNF, SEE TRANSLATION}

bola_gila Selamat sekali lagi buat @realmadrid, mimpi indah buat para

Dede cules jangan iri. Kalo gasuka Madrid juara mendingan diem aja

Gambar 4. Bentuk kalimat caption dalam postingan Admin Instagram @bola_gila yang bernada menyindir.

Lewat caption tersebut, kita dapat menduga bahwa memang adanya kalimat sindiran dari admin Instagram, yang kelak akan memancing fans Barcelona juga terlibat dalam tawuran virtual ini. Sebenarnya, yang menjadikan studi kasus berita final Liga Champions 2017 ini menarik adalah, hilangnya suara fans Juventus dalam perselisihan dikolom komentar. Berdasarkan observasi teks yang dilakukan peneliti dalam 1395 komentar, hanya sekitar 50 atau 4\% komentar saja yang menggambarkan dan menyeruakan suara hati fans Juventus. Justru fans Barcelona yang mengambil alih proses percakapan dan turut menjadi aktor utama dalam tawuran virtual ini.

Peneliti juga melakukan eksperimen dalam penelitian ini, dengan melibatkan postingan dari salah satu Intagram bertemakan sepakbola yang paling aktif di Indonesia. Dalam postingan akun
@ berita_sepakbola pada tanggal 4 juni 2017 terkait final Liga Chamopins, mereka menuliskan caption yang bersifat netral dan tidak memancing pihak tertentu. Namun yang unik adalah, dari 261 komentar yang muncul di kolom komentar, proses tawuran virtual tetap terjadi dan tetap melibatkan fans Barcelona didalamnya.

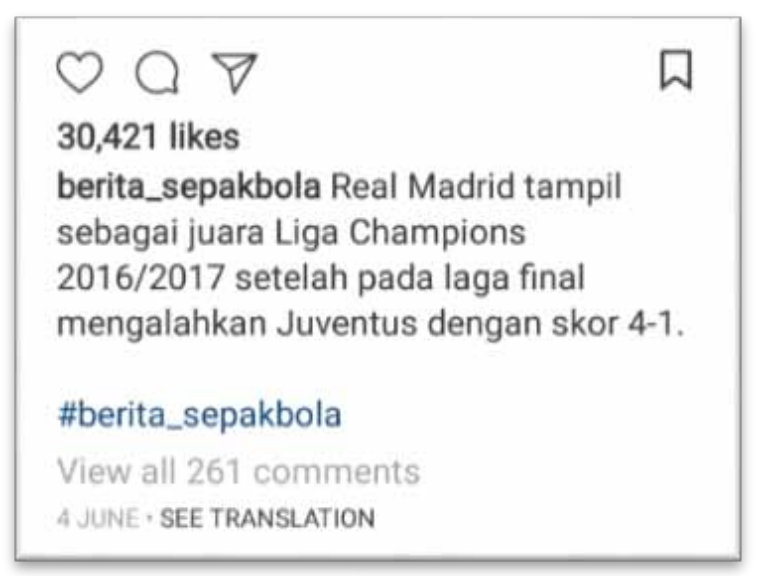

Gambar 5. Bentuk kalimat caption dalam postingan Admin (a)berita_sepakbola yang bernada netral.

Berdasarkan data dua media Instagram diatas, peneliti menganalisis dan mengobservasi 1656 komentar dari total jumlah komentar kedua akun Intagram tersebut. Percakapan yang timbul dalam kedua kolom komentar tersebut cukup beragam, dan berhasil merumuskan lima karakteristik utama fans sepakbola di Indonesia:

Karakter Sportif. Karakteristik fans yang memiliki sifat sportif, dapat dilihat dari kesiapan mentalnya untuk tidak mau terlibat dalam tawuran virtual. Biasanya mereka akan bersuara sesudah pertandingan selesai, dan menyampaikan selamat atas kemenangan klub lawan tanpa memberikan kalimat ejekan atau sindiran. Selain itu, biasanya tipe fans seperti ini hanya akan keluar satu kali dalam kolom komentar, tanpa diikuti oleh komentar berikutnya.

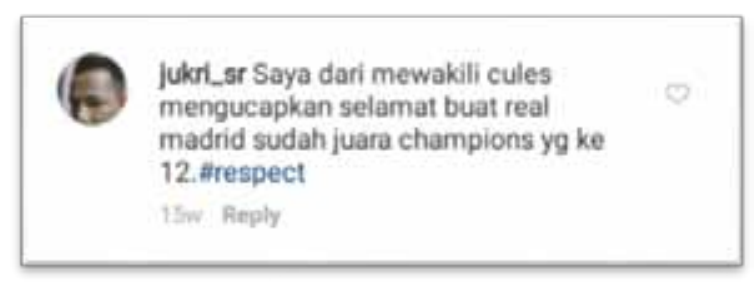

Gambar 6. Contoh fans sepakbola dengan karakter sportif. 
Karakter Netral. Karakter fans yang memiliki sifat netral biasanya bukan merupakan fans dari salah satu klub yang bertanding. Mereka hanyalah penikmat sepakbola, yang menjadi followers akun sosial media dan kerap berkomentar mengenai berita sepakbola yang sedang hangat. Tipe fans seperti ini akan muncul ditengah-tengah perdebatan, dan biasanya akan mengisi komentar tanpa menyinggung indikasi isu perselishan yang mulai panas. Seperti yang terlihat dalam contoh postingan dibawah ini:

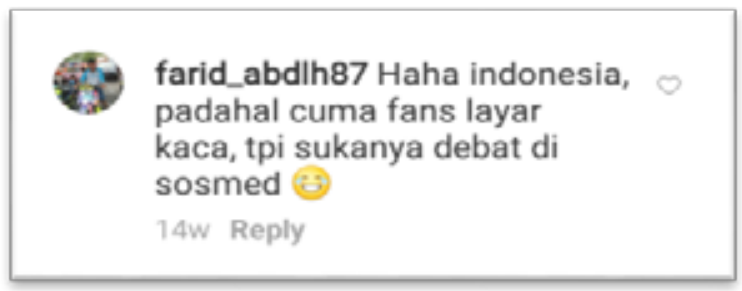

Gambar 7. Contoh fans sepakbola dengan karakter netral.

Karakter Mencoba Menengahi. Karakteristik fans seperti ini acapkali muncul dalam percakapan yang didefnisikan sebagai tawuran virtual di media sosial. Sebenarnya, fans sepakbola dengan karakteristik ini mempunyai hati yang mulia dan maksud yang baik. Niat tulus untuk mendamaikan kedua kubu yang sedang panas, terkadang tidak diikuti dengan usaha tepat oleh fans kedua kubu. Fans dengan karakter seperti ini akan muncul ketika proses perdebatan mulai terlihat, dan ketika tawuran sedang mencapai puncaknya. Seperti dalam gambar berikut:

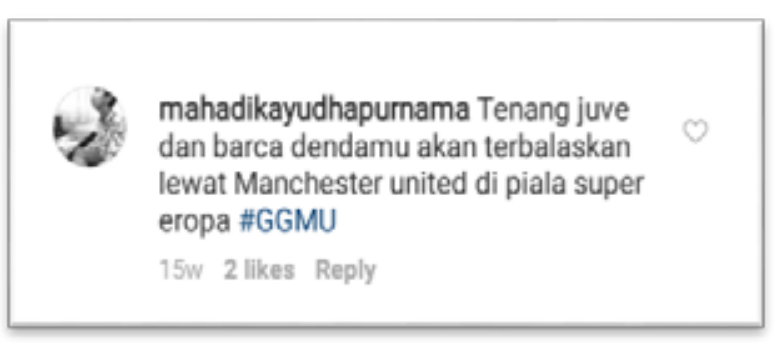

Gambar 8. Contoh fans dengan karakter yang mencoba menengahi.

Karakter Cepat Panas. Karakter fans sepakbola yang mengedepankan emosi cukup sering menjadi bibit maupun benih dari tawuran virtual. Emosi yang terlalu mudah dipancing dan kerap kali buta mata dengan langsung melawan fans klub lawan, tanpa memperhatikan etika yang ada dalam menggunakan media sosial. Seringkali karakter fans seperti ini disebut sebagai "fans sumbu pendek" yang lebih dimaksudkan cepat sekali emosi dan marah sehingga tawuran dapat berlangsung panas dan lama. Adapun dalam observasi teks yang dilakukan, peneliti berhasil membagi fans karakter "cepat panas" ini dalam empat tipe yang berbeda. Pembagian tipe pun didasari oleh alasan utama atau indikator pemicu. Alasan utama fans dengan karakter ini cepat panas adalah, karena klub yang disanjung dan dicintainya diejek oleh fans klub sepakbola lawan. Terkadang ejekan yang diberikan tidak selalu bersifat besar, namun karena "bersumbu pendek" maka proses perang kata-kata dan adu mulut dalam sosial media tidak dapat erelakan. Gambar dibawah ini adalah salah satu contoh fans yang cepat panas karena komentar dari fans lain yang menyinggung klub kebanggannya.

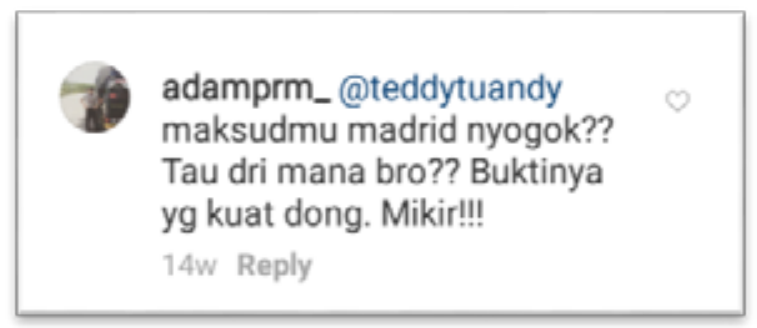

Gambar 9. Contoh karakter fans cepat panas dengan pemicu klub kesayangan diejek.

Alasan lain, sesorang maupun sekelompok fans menjadi cepat marah dan menimbulkan tawuran adalah ketika pemain idola dalam klub kesayangnnya turut diejek oleh fans klub lain. Ejekan yang diberikan bisa berupa jeleknya permainan yang dibawakan hingga menyamakan kemampuan sang idola dengan pemain yang bukan berlabel bintang. Biasanya fans tersebut akan marah, dan mencaci maki seperti gambar dibawah ini:

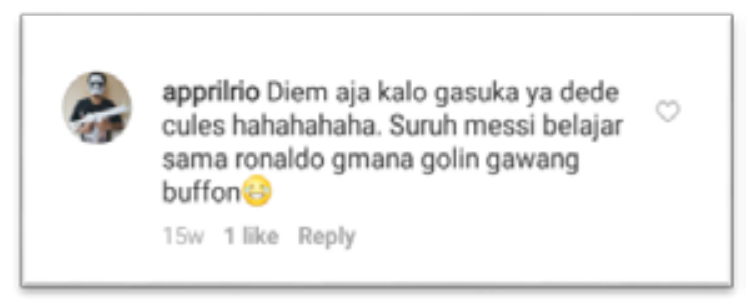

Gambar 10. Contoh karakter fans cepat panas dengan pemicu klub kesayangan diejek. 
Pemicu lain yang dapat menyebabkan tawuran virtual yang beangkat dari karakter fans yang cepat panas adalah melawan komentar dari fans lain yang sok tahu, dan memberikan pendapatnya tanpa mengetahui pokok bahasan dan arah alur bahasan dalam pertengakaran komentar. Biasanya fans dengan karakter yang mencoba menengahi akan memberikan kalimat wejangan atau kalimat pendingin agar tawuran berhenti dan tidak berlanjut. Namun terkadang, kalimat yang diberikan juga bisa menjadi "blunder" dan tampak seperti kalimat yang mengandung unsur ketidakpercayaan atau "sok tahu". Seperti yang terlihat dari amarah komentar dalam gambar dibawah ini:

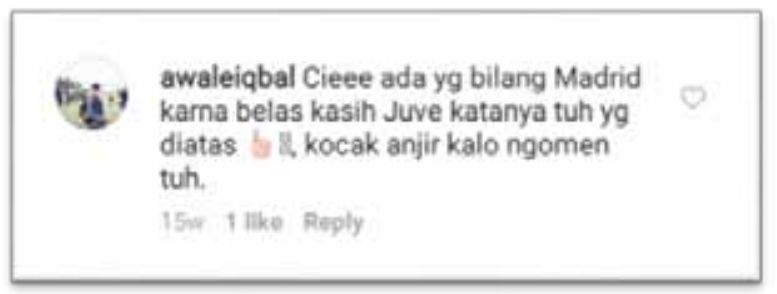

Gambar 11. Contoh karakter fans cepat panas dengan pemicu fans yang sok tahu.

Salah satu alasan lain yang turut memicu tawuran dalam dunia maya adalah postingan atau komentar yang mengandung kesombongan dari salah satu fans klub yang terlalu membanggakan klub idolanya. Alasan yang satu ini berbeda dengan dengan alasan pertama yang mengejek klub lain, karena dalam konteks ini fans hanya memberikan postingan yang menunjukan prestasi klubnya, tanpa tertuju kepada klub lawan. Namun dalam observasi peneliti, sebenarnya proses komparasi gelar juara seperti ini juga lama-lama kan menimbulkan kemarahan dan perselisihan. Seperti gambar dibawah ini:

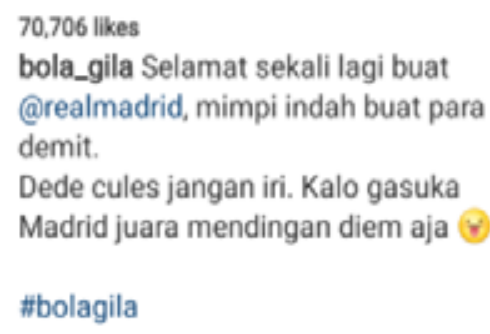

Gambar 12. Contoh karakter fans cepat panas dengan kesombongan fans lain.
Selalu ada antonim atau kebalikan dari setiap karakter yang terlibat dalam sebuah konflik. Layaknya peribahasa "ada asap ada api" maka dalam konteks tawuran virtual, setiap fans yang cepat panas dan tersulut emosinya, pasti dipicu oleh posingan fans yang bersfat menjurus dan sangat provokatif. Karakter ini cukup berbahaya dan biasanya menjadi "penabur bensin" dalam proses tawuran. Postingan yang awalnya bersifat netral dapat berubah menjadi panas dan ramai dengan tawuran karena karakter provokatif yang satu ini. Peneliti behasil memecah karakter ini kedalam empat tipe yang dilatarbelakangi oleh tujuan provokasi.

Berdasarkan observasi peneliti, tujuan yang pertama ini adalah yang paling sering menjadi sumbu utama dalam proses tawuran virtual. Akan selalu ada satu atau sekelompok fans yang memberikan komentar yang langsung bertujuan untuk menyindir hingga menjelek-jelekan klub lain, tanpa membanding-bandingkan prestasi klub kebanggannya. Berikut ini adalah contoh dari postingan komentar yang memprovokasi tawuran lewat ejekan:

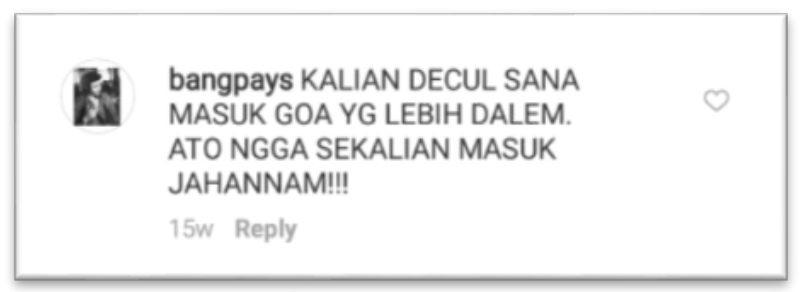

Gambar 13. Bentuk komentar yang bersifat provokatif dengan mengejek klub lain.

Tujuan lain yang cukup berbahaya adalah dengan membanding-bandingkan prestasi klub lawan. Dalam konteks tawuran, hal ini dapat menjadi pemicu utama fans lawan marah dan menyerang balik. Gelar dan kemenangan menjadi kunci utama dari startegi provokasi dalam karakter provokator yang menggunakan tujuan ini. Seperti yang terlihat dalam gambar dibawah ini:

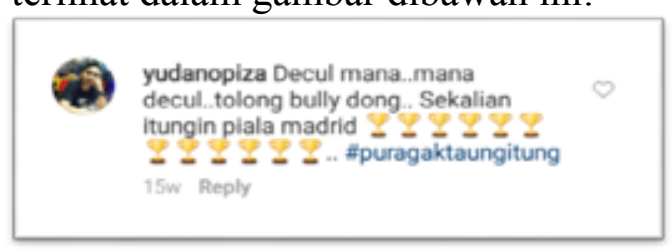

Gambar 14. Bentuk komentar yang bersifat provokatif dengan membandingkan gelar. 
Tujuan yang satu ini lebih sering menjadi provokator dengan menyulut amarah salah satu orang saja, dan terkesan tidak ingin membesar dalam lingkup yang lebih luas. Tujuan yang satu ini secara psikologis lebih berhasil memancing amarah, karena spesifik tertuju kepada salah satu orang saja. Sehingga secara emosi juga membuat lawan yang dituju cepat panas dan menimbulkan kegaduhan. Contohnya alam gambar berikut:

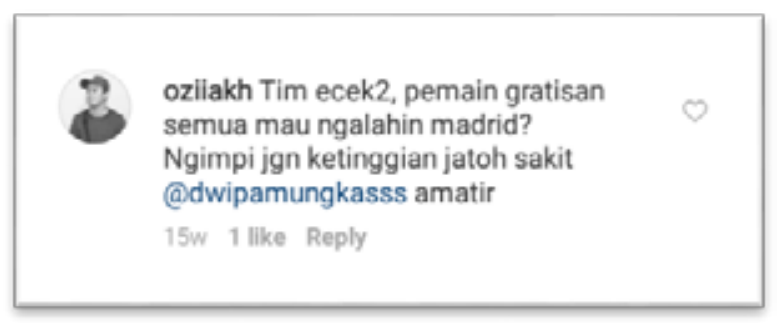

Gambar 15. Bentuk komentar yang bersifat provokatif dengan menuju salah satu orang.

Berbeda dengan ketiga tujuan yang lain, terkadang ada juga fans yang mencoba menjadi "penambah bumbu" pertengkaran dengan berlindung dibalik pundak orang. Dalam hal ini jika proses tawuran dimulai dari postingan admin yang memihak salah satu pihak, atau menyindir klub lain, maka akan ada fans yang bertujuan provokatif dengan dalih mendukung admin, adapun niat sebenarnya adalah menambah panas pertengkaran yang sudah terjadi. Hal ini dapat dilihat dari contoh gambar dibawah ini:

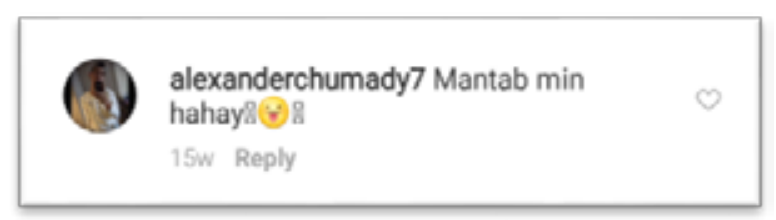

Gambar 16. Bentuk komentar yang bersifat provokatif dengan mendukung admin.

Setelah memahami masing-masing karakterstik dari fans sepakbola yang terlibat tawuran virtual, serta turut diberikan hubungan yang jelas antara tujuan dan alasan karakter dari pelaku dan pemicu tawuran virtual, maka peneliti merumuskan seluruh elemen dalam diagram diatas, yang didalamnya menggambarkan bagaimana beragam karakter dari fans sepakbola turut mempengaruhi terjadinya tawuran virtual yang kerap terjadi di sosial media. Dapat dilihat dari gambar olahan peneliti (lihat gambar 17) bahwa karakter fans sepakbola dapat dibagi menjadi lima karakter yang berbeda, dimana dua karakter terakhir yakni "cepat panas" dan "provokator" menghasilkan beberapa turunan yang merupakan wujud dari alasan dan tujuan masing-maisng karakter.

Peneliti berhasl menjaring dan menemukan tiga bentuk kemarahan yang biasanya tertuang dalam tawuran virtual. Antara lain seperti pengunaan kata maupun kalmat tidak pantas, penggunaan "capslock" yang kerap menandakan marah yang sangat besar, hingga penggunaan kata-kata yang bersifat ancaman. Peneliti akan mendetailkan keempat bentuk kemarahan tersebut dalam penjelasan dibawah ini. Seperti yang telah diungkapkan dalam penjelasan pada bagian karakteristikfans, bahwa terdapat lima karakteristik yang berbeda yang dapat digambarkan oleh fans sepakbola yang terlibat dalam tawuran virtual. Ketika terlibat tawuran, beberapa jenis karakter tetap akan menunjukan kemarahannya lewat katakata. Dikarenakan medium yang digunakan adalah sosial media yang tidak dapat menghasilkan aksi langsung, maka digunakanlah kata-kata kasar yang mengandung amarah untuk meluapkan emosi yang ada. Selain itu, kelemahan sosial media yang hanya dibalut oleh undang-undang informasi dan transaksi elektronik, maka seolah-olah membebaskan pengikutnya untuk bebas berkata tanpa ada penyaringan yang tepat. Berdasarkan observasi peneliti, penggunaan kata kasar dan tidak pantas yang terlihat dari kolom komentar kedua akun berjumlah kurang lebih 500 kali, atau 35\% dari total komentar. Ini adalah bentuk kemarahan yang paling mudah diluapkan. (Lihat gambar 18).

Berbeda dengan penggunaan kalimat kasar serta tidak pantas yang sangat mudah ditulis dan diucapkan, bentuk kemarahan yang satu ini memerlukan fokus tertentu kepada salah seorang fans maupun admin sosial media yang dituju. Ancaman yang diberikan dapat beragam, seperti melakukan unfollow akun, hingga meng-hack situs akun, bahkan yang mengajak bertemu diluar. Namun, salah satu ciri dari tawuran virtual adalah kecilnay kemungkinan terjadinya kekerasan anarkis yang beakibat pada kerusakan fisik seperti yang terlihat dalam tawuran sepakbola nyata. Jika melihat dalam studi kasus ini, bentuk ancaman kerapkali terjadi dalam 220 komentar yang ada 


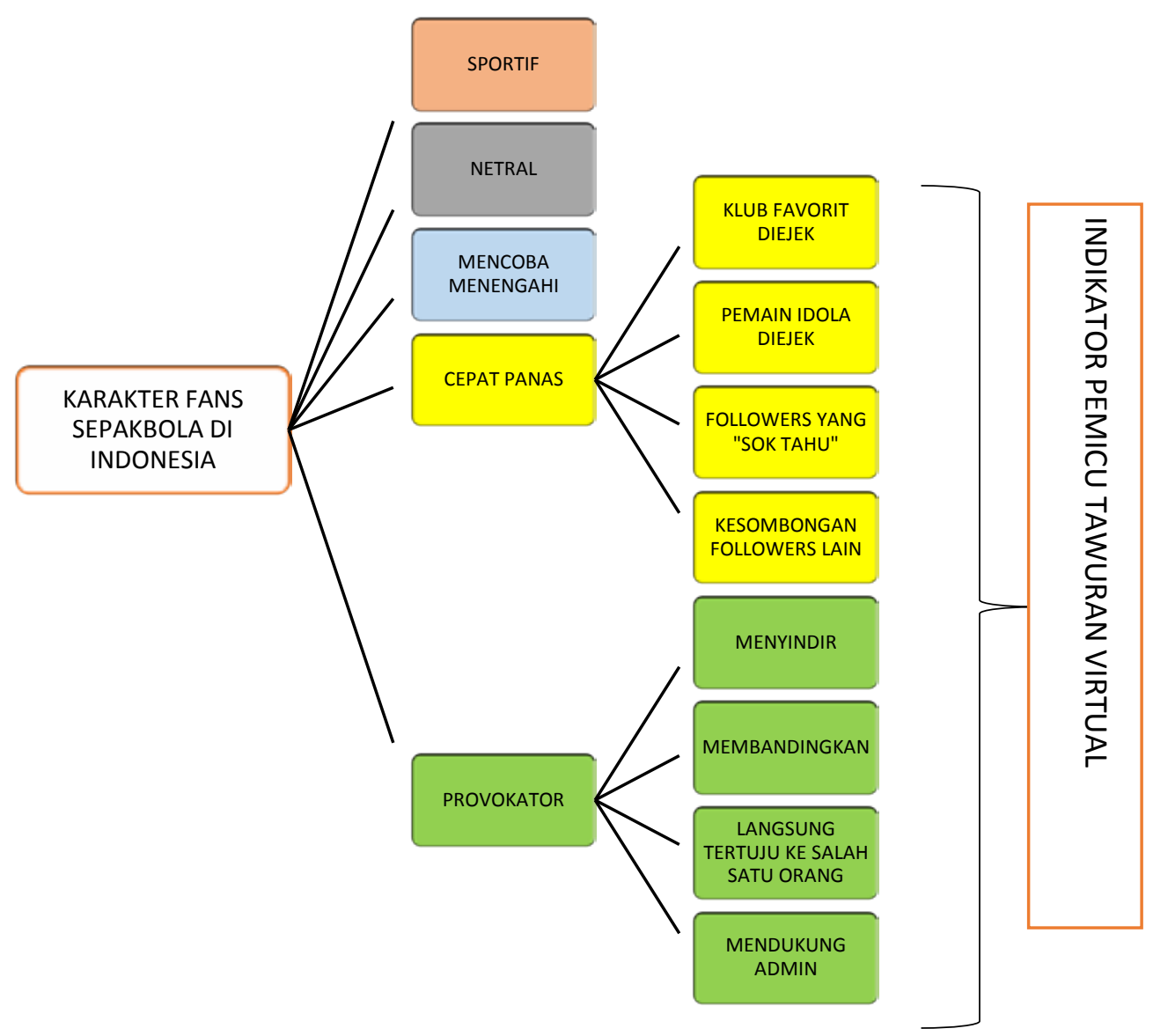

Gambar 17. Deskripsi karakteristik serta indikator pemicu tawuran fans sepakbola di Indonesia lewat analisis konten berdasarkan percakapan dalam kolom komentar intagram

(Sumber: data olahan peneliti, 2017)

(sekitar 15\%) dari total komentar dari kedua akun intagram. Salah satu bentuk ancaman yang kerap terjadi. (Lihat Gambar 19).

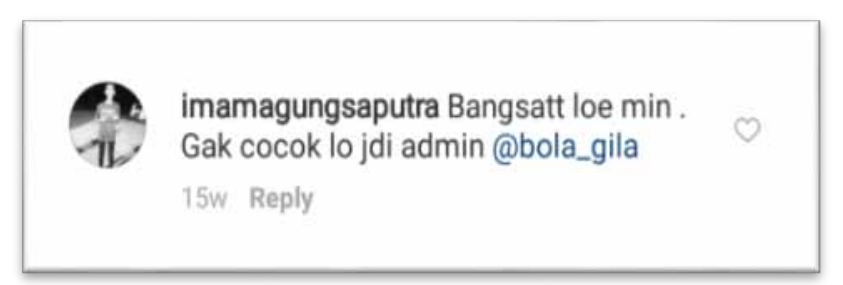

Gambar 18. Contoh bentuk kemarahan yang menggunakan kata-kata kasar.

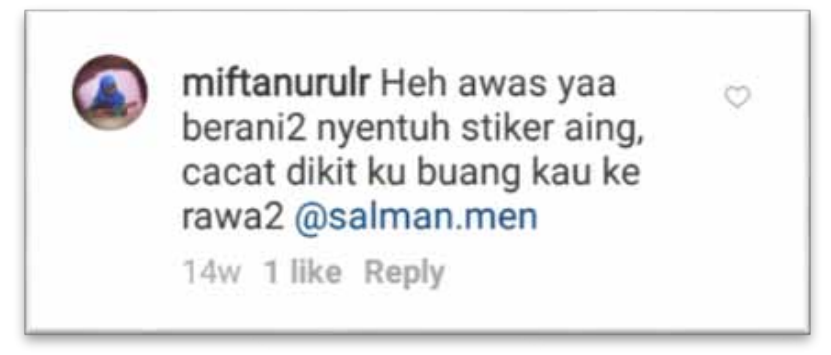

Gambar 19. Contoh bentuk kemarahan yang menggunakan kata-kata ancaman.
Penggunaan tanda baca yang ditulis besar (sering disebut Capslock) merupakan langkah simbolik yang menunjukan bahwa orang tersebut sangat marah sehingga ingin menunjukan emosinya tidak hanya lewat kata-kata yang ditulis, namun juga melewati struktur kata-kata yang ditulis. Penggunaan capslock sering diartikan sebagai marah yang cukup terkendali, dan sangat sering terlihat dalam setiap tawuran virtual yang ada.Dalam studi kasus ini, peneliti berhasil menghimpun 135 komentar (atau hanya 9\% dari total komentar) yang menggunakan capslock untuk menandakan kemarahan mereka. Seperti pada gambar dibawah ini:

\section{3. bangpays DECUL BIGOT IDIOT}

$15 w$ Reply

Gambar 20. Contoh bentuk kemarahan yang menggunakan "capslock". 
Untuk mempermudah pemahaman dalam penelitian ini, peneliti merangkum ketiga bentuk kemarahan yang sering terjadi dalam tawuran virtual lewat diagram dibawh ini. Jika diukur dari porsi bentuk kemarahan yang sering terjadi, maka urutannya adalah penggunaan kata kasar dan tidak pantas ada dilevel pertama yang paling sering digunakan. Diikuti oleh bentuk kemarahan lewat kalimat ancaman, serta penggunaan capslock yang cukup jarang menjadi bentuk terakhir yang sagat jarang digunakan.

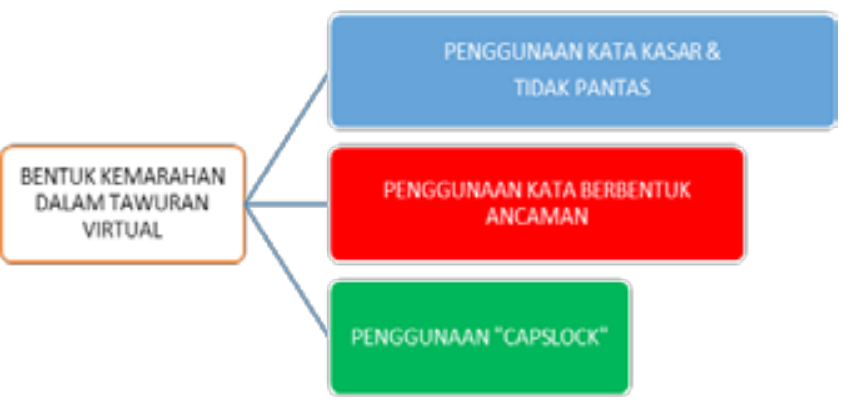

Gambar 21. Hasil deskripsi bentuk kemarahan yang biasa tertuang dalam "tawuran virtual" fans sepakbola di Indonesia dalam kolom komentar Instagram.

(Sumber: data olahan peneliti, 2017

\section{SIMPULAN}

Elemen pertama yang berhasil dibongkar dalam penelitian ini adalah pola tawuran virtual yang tidak hanya meliputi dua kubu saja. Pola yang terjadi lebih kompleks, karena meliputi admin sebagai pihak utama yang memberikan caption pembuka, bahkan masuknya fans yang bersfat netral yang berniat untuk melerai perang katakata. Cukup kompleks, karena melibatkan empat unsur yang berbeda, serta pola yang terjadi cukup variatif dengan saling menyerang antar kubu, bahkan adanya pola penyerangan masing-masing kubu terhadap admin sosial media.

Elemen lain yang dibongkar oleh peneliti meliputi karakteristik fans sepakbola yang terlibat dalam tawuran virtual. Secara garis besar terdapat lima karakter berbeda, yakni fans yang bersifat sportif, menghargai lawan, bersifat netral, tidak ambil bagian dalam perselisishan, fans yang bersifat menengahi, serta dua karakter yang menjadi aktor utama dalam proses tawuran yakni, fans dengan karakter cepat panas serta karakter fans yang provokator atau memancing keributan. Masingmaisng karakter juga berhasil membentuk elemen tersendiri yang akhirnya juga ikut terbongkar dalam penelitian ini, yaitu perkara indikator atau pemicu tawuran. Dapat ditemukan delapan indiktor pemicu tawuran yang biasanya sering digunakan, antara lain klub idola yang diejek, pemain favorit yang disindir, hingga masalah seperti menyombongkan gelar klub kebanggannya.

Dengan terpecahkannya indikator pemicu tawuran, maka elemen berikutnya yakni bentuk kemarahan yang kerap terjadi dalam tawuran virtual juga mulai terlihat jelas. Bentuk kemarahan yang beragam, dari penggunaan kata-kata kasar, kalimat bernada ancaman, hingga penggunaan simbol capslock merupakan bentuk kemarahan yang paling menggambarkan kemarahan fans. Dimana porsi penggunaan kata-kata kasar dan tidak pantas adalah bentuk kemarahan yang paling awam digunakan.

Penelitian ini juga menyisakan beberapa kunci penting lain yang dapat diteliti dalam penelitian selanjutnya. Persoalan kebebasan bereksprsi serta tidak adanya literasi dan penyuntingan dalam penggunaan kata-kata kasar dan tidak pantas selama proses tawuran, haruslah menjadi pekerjaan rumah tersendiri untuk penelitian dalam kajian kebijakan media dan kode etik media, terutama penggunaan UU ITE. Sisi lain yang juga perlu dikaji lebih dalam adalah motif terselubung dari pemilik akun sosial media yang kerap memancing terjadinya tawuran. Perlu diperhatikan bahwa ada kesempatan lain yang kerap digunakan oleh pemilik akun sebagai ladang bisnis, kaitannya dengan monetisasi yang mengolah proses tawuran menjadi keuntungan materiil tersendiri.

\section{DAFTAR PUSTAKA}

Anshari, Faridhian \& Prastya, Narayana M. 2014. Membaca Kompetisi Harian Olahraga di Indonesia, Menggunakan pendekatan Structure, Conduct, Performance. Proceeding Indonesia Media Research Awards Summit 1st. Serikat Pekerja Suratkabar Indonesia. Jakarta. Hal 14.

Arianti Gusmia. 2017. Kepuasan Remaja Terhadap Penggunaan Media Sosial Instagram dan Path. Jurnal Wacana Jurnal Ilmiah Ilmu Komunikasi Vol 16, No 02, (hal 180 - 192). 
Boyle, Raymond \& Richard Haynes. 2009. Power, Play, Sport, the Media, and Popular Culture. Second Edition. Edinburgh University Press Ltd. UK

Carnibella, Giovanni, Fox, Anne, Fox, Kate \& McCann, Joe. 1996. Football Violence in Europe. SIRC, Social Issue Rsearch Centre Publications. UK

Cashmore, Ellis \& Cleland, Jamie. 2014. Football's Dark Side. Corruption, Homophobia, Violence and Racism in The Beautiful Game. Pallgrave Macmillan. UK

Foer, Franklin. 2006. Memahami Dunia Lewat Sepakbola. Marjin Kiri. Jakarta

Giulianotti, Richard. 2006. Football: A Sociology of the Game. Polity Press. Cambridge.UK.

Jacobson, Beth. 2003. The Social Psychology of the Creation of a Sport Fan Identity: A Theoretical Review of the Literature. Athletic Insight, Volume 5, Issues 2. USA

Kamus Besar Bahasa Indonesia, Edisi Keempat, 2008, Gramedia Pustaka. Utama, Jakarta.

McQuaill, Dennis.2010. Teori Komunikasi Massa Edisi Kelima. Erlangga. Jakarta.

Mey, Jacob L. 2001. Pragmatics: An Introduction. Blackwell Publishing. Asutralia.

Munro, Clayton Edward Steven. 2006. Sports Fan Culture \& Brand Community; An Ethnographic Case Study of The Vancouver Canucks Boster Clubs. Faculty of Graduated Studies. University of British Columbia. USA

Nugraha, Ubaidillah. 2008. Republik Gila Bola.
Ufuk Press. Jakarta

Simaepa, Darmanto. 2016. Tamasya Bola, Cinta, Gairah, dan Luka dalam Sepakbola. Penerbit Buku Mojok. DIY

Syahputra, Iswandi. 2016. Pemuja Sepakbola, Kuasa Media Atas budaya. Gramedia Pustaka Utama. Jakarta

Wimmer, Roger \& Dominick, Joseph. 2011. Mass Media Research: An Introduction, Ninth Edition. Wadsworth. USA

Admin Instagram @bola_gila. 2017. Caption Final Liga champions 2017 Real Madrid vs Juventus._https://www.instagram.com/p/ BU7EAdNg0_z/?taken-by=bola_gila Diunduh tanggal 1 Juli 2017

Admin Instagram @berita_sepakbola. 2017. Caption Final Liga champions 2017 Real Madrid vs Juventus. https://www. instagram.com/p/BU5EuauASUC/?takenby=berita_sepakbola . Diunduh tanggal 1 Juli 2017

Nugroho, Agung. 2017. 5 Klub Eropa yang Memiliki Jumlah Supporter Terbanyak di Indonesia. https://www.cultureindo. com/9149/2017/04/18/5-klub-eropa-yangmemiliki-jumlah-suporter-terbanyak/ diunduh pada tanggal 10 Juli 2017

Staff Kemeneterian Pemuda dan Olahraga. 2015. Imlek dan Olahraga Indonesia. http://m.kemenpora.go.id/index/preview/ berita/295/4 diunduh pada 10 Juli 2017 